\title{
Periodic picophytoplankton predominance in a large, shallow alkaline lake (Lake Fertő, Neusiedlersee)
}

\author{
Boglárka Somogyi ${ }^{1 *}$, Tamás Felföldi ${ }^{2}$, Mária Dinka ${ }^{3}$ and Lajos Vörös ${ }^{1}$ \\ 1 Balaton Limnological Research Institute of the HAS, 8237 Tihany, Klebelsberg K. 3., Hungary \\ 2 Department of Microbiology, Eötvös Loránd University, 1117 Budapest, Pázmány P. 1/c., Hungary \\ 3 Hungarian Danube Research Station of the HAS, 2163 Vácrátót, Alkotmány 2-4., Hungary
}

Received 12 February 2009; Accepted 28 October 2009

\begin{abstract}
The biomass and composition of the phytoplankton was studied at seven sampling stations located at different water bodies (open water, inner pond and canal) of a large, shallow turbid lake (Lake Fertö, Neusiedlersee). The open water was characterized by picocyanobacteria and meroplanktonic diatoms, the artificial canal by epiphytic diatoms, cryptophytes and chlorophytes. The inner ponds, based on the phytoplankton composition, were positioned between these water bodies. High picoplankton abundance $\left(>10^{6}\right.$ cells. $\left.\mathrm{mL}^{-1}\right)$ and predominance (up to $80 \%$ contribution to the total phytoplankton biomass) were detected in the open water and the inner ponds, which was hypothesized to be the result of the turbid environment by the suppression of the top down control and by light-limitation. Information on the diversity of the picoplankton in the open water of the lake has been presented first time in this study. Based on molecular analysis (16S rRNA gene and $c p c B A$-IGS region) the dominant group of picocyanobacteria belonged to the Cyanobium gracile cluster (group A) of the picophytoplankton clade in April. Members of two other picocyanobacterial groups (group B and C) were also detected.
\end{abstract}

Key words: Phytoplankton composition / autotrophic picoplankton / molecular analysis / water transparency / Lake Fertő

\section{Introduction}

Lake Fertö (Neusiedlersee) is the largest shallow alkaline lake in Central Europe located at the AustrianHungarian border. About $55 \%$ of the whole lake $\left(309 \mathrm{~km}^{2}\right)$ and $85 \%$ of the Hungarian part $\left(75 \mathrm{~km}^{2}\right)$ is covered by reed. There are numerous reedless brownwater ponds (inner ponds) of variable size within the reed belt, which is enmeshed with artificial canals connecting the inner ponds with the open water areas. More or less heterogenenity can be found in the physical and chemical parameters of different water bodies in the lake (open water, inner ponds and canals), but its degree is basically determined by the distance of the enclosed regions from the open water areas and the water level of the actual year (Dinka et al., 2004). The open water area and the inner ponds have similar ion composition, $\mathrm{pH}$ and conductivity, but there are great differences in their transparency (Dinka et al., 2004). The open water of the lake is extremely turbid, the apparent colour of the water varies between

\footnotetext{
*Corresponding author: boglarka@tres.blki.hu
}

greenish, grey and white according to weather conditions and turbidity concentration (Dokulil, 1979). The observable grey or white colour is the result of the high concentration of total suspended inorganic particles in the water column (Dokulil, 1979). This high suspended solid concentration is stirred up from the bottom by wind action and due to the shallowness of the lake. The inner ponds and the canals are more sheltered from windinduced mixing and exhibit therefore a higher transparency. Water inside the reed belt is invariably coloured brown by humic substances (Dokulil, 1979). An increasing conductivity and $\mathrm{pH}$ gradient is observable along the canals from the shore to the open water (Dinka et al., 2004).

The intensive algological investigation of Lake Fertö in the last century resulted in an exhaustive long list of species (Tevanné, 1981; Padisák, 1992; Padisák and Dokulil, 1994). The larger algae (nano- and microplankton) of the open water and the inner ponds are wellknown, especially planktonic and epiphytic diatoms were in the focus of the studies (Buczkó, 1989). Instead of the traditional light microscopic methods, the quantification 
and the identification of the pico-sized microorganisms require epifluorescent microscopic methods and molecular biological tools. The diversity of planktonic bacteria in Lake Fertő has also been characterized (Borsodi et al., 1998), but we have only a few information about the autotrophic picoplankton (Felföldi et al., 2009). The autotrophic picoplankton is a size classification (usually defined as cells with diameter $<2$ or $3 \mu \mathrm{m}$ that are present even in single-celled or colonial forms) thus species composition can vary from lake to lake (Callieri, 2008). Except some colonial species, having cells that may approach the pico-size range and have identifiable morphological features, like the cyanobacterial genera Merismopedia, Cyanodictyon or Aphanothece (Stockner et al., 2000), the picoalgae are not identifiable by traditional microscopic methods. In Lake Fertő, only Padisák and Dokulil (1994) studied quantitatively the autotrophic picoplankton in the open water area based on offshore samples from the Illmitz Bay (Padisák and Dokulil, 1994). This study emphasized the importance of picoplankton investigations avoiding underestimation of the phytoplankton biomass.

In shallow mesotrophic lakes the abundance of the picoplankton ranges usually from $10^{4}$ to $10^{5}$ cells. $\mathrm{mL}^{-1}$ (Jasser, 1997; Szelag-Wasielewska, 2003; Mózes et al., 2006); however studies on Lake Balaton (Hungary), Lake Fertő (Hungary/Austria) and Lake Sekacz (Poland) describe one magnitude higher values (Vörös, 1989; Padisák and Dokulil, 1994; Szelag-Wasielewska, 1997). The contribution of the picoplankton to the total phytoplankton biomass in shallow mesotrophic lakes is usually between 1 and 17\% (Vörös, 1989; Jasser, 1997; Szelag-Wasielewska, 1997; Szelag-Wasielewska, 2003). On the other hand, in the open water of Lake Fertö, the picoplankton contributed $75 \%$ of the total phytoplankton biomass in April 1992 (Padisák and Dokulil, 1994). The study of Padisák and Dokulil (1994) revealed the important role of picoplankton in the open water of Lake Fertö; however, their composition and seasonal dynamics remained unknown and we have no information about their prevalence in other areas of the lake nonetheless the reed covers more than half of the surface area.

This paper describes the first results regarding the composition and dynamics of autotrophic picoplankton and its contribution to the total phytoplankton biomass in different water bodies (open water, inner ponds and canals) of Lake Fertő. As the identification of these microorganisms is not possible on the basis of classical methods, molecular biological tools were applied to determine the major groups of picoplankton in the open water.

\section{Methods}

\section{Study site and sampling}

Lake Fertő is a meso-eutrophic, shallow, alkaline lake. For microscopic examinations, samples were taken from seven stations in the Hungarian part of the lake (Table 1) bimonthly between April and October 2004. We studied the turbid open-water area of the lake (Stn. 1 and Stn. 2), three brown-water inner ponds enclosed with reed belt (Stn. 3, Stn. 4 and Stn. 5) and an artificial canal within the reed belt (Stn. 6 and Stn. 7). The surface area of the investigated inner ponds varied within a wide range (Stn. 3: 35 ha, Stn. 4: 15 ha and Stn. 5: 1.5 ha). Samples for molecular studies were taken from Stn. 1 and Stn. 2 in April 2004. Three sampling stations (Stn. 3, Stn. 6 and Stn. 7) were unapproachable in August 2004 due to the low water level of the lake. Coordinates of the sampling stations were determined with Garmin GPS (76Cx). The $\mathrm{pH}$ and conductivity of the water samples were measured with WTW MultiLine portable field meter (P 8211). The total suspended solid concentration was determined gravimetrically (Eaton et al., 1995). Secchi-disk transparency data of the different sampling stations were provided by the North-Transdanubian Water Authority (Hungary).

\section{Algological investigations}

The chlorophyll $a$ concentration of the phytoplankton was determined spectrophotometrically after hot methanol extraction according to Wetzel and Likens (1991). The nano- and microplankton samples were fixed by Lugol-solution, their abundance and composition were determined with an inverted microscope (Utermöhl, 1958). The abundance and composition of the picoplankton were determined using fresh, unpreserved samples. Aliquots of 1-3 mL were filtered onto black polycarbonate filters having $0.4 \mu \mathrm{m}$ pore-size. The filters were placed on a microscopy slide, embedded into $50 \%$ glycerol. The slides were examined with Nikon Optiphot 2 epifluorescence microscope with $1000 \times$ magnification, using blue-violet (BV-2A) and green (G-2A) excitation light. At least 20 fields (400 cells) were photographed with a Spot RT color camera and the picoalgae were counted on these pictures to avoid the fluorescence fading. Solitary cells, loose aggregates and small colonies were all considered to be picoplanktonic organisms if the cell size was less than $2 \mu \mathrm{m}$ according to Stockner et al. (2000). Using the routine enumeration protocol for identifying picophytoplankton types, first the picophytoplankton cells were located under blue-violet excitation. Picoeukaryotes show deep red fluorescence under this excitation due to chlorophyll $a$. Phycoerythrin-rich picocyanobacteria fluoresce bright yellow-orange under violet-blue excitation light, while phycocyanin-rich picocyanobacteria show only weak red autofluorescence. Switching to green excitation for the same field, picoeukaryotic cells do not show (or just a very weak) autofluorescence. The main property distinguishing between eukaryotes and cyanobacteria under epifluorescence microscope is the presence of phycobiliproteins, which show greatly enhanced (red) autofluorescence using green waveband (MacIsaac and Stockner, 1993).

The total biovolume of the nano- and microplankton was calculated on the basis of cell volume and abundance values (counted by inverted microscope, Utermöhl, 1958). 
Table 1. Selected physical and chemical parameters of the sampling stations in Lake Fertö (Neusiedlersee).

\begin{tabular}{|c|c|c|c|c|c|c|c|c|}
\hline & Name & $\begin{array}{c}\text { Coordinates } \\
\mathrm{N}\end{array}$ & $\underset{E}{\text { Coordinates }}$ & $\begin{array}{l}\text { Water } \\
\text { depth } \\
(\mathrm{m})\end{array}$ & $\begin{array}{c}\text { Secchi-disk } \\
\text { transparency* } \\
\text { (cm) }\end{array}$ & $\begin{array}{l}\text { Suspended } \\
\text { solids } \\
\left(\mathrm{mg}^{-1} \mathrm{~L}^{-1}\right)\end{array}$ & $\begin{array}{l}\text { Conductivity } \\
\left(\mu \mathrm{S} . \mathrm{cm}^{-1}\right)\end{array}$ & $\mathrm{pH}$ \\
\hline$\overline{\text { Stn. } 1}$ & Open water & $47^{\circ} 41.601^{\prime}$ & $16^{\circ} 43.835^{\prime}$ & $0.6-1.0$ & $2.5-30$ & $20-260$ & $2300-3000$ & $9.0-9.3$ \\
\hline Stn. 2 & Rákosi-bay & $47^{\circ} 43.084^{\prime}$ & $16^{\circ} 42.102^{\prime}$ & $1.2-1.4$ & $2.5-30$ & $12-235$ & $2200-3000$ & 8.9-9.2 \\
\hline Stn. 3 & Herlakni inner pond & $47^{\circ} 41.204^{\prime}$ & $16^{\circ} 42.783^{\prime}$ & $1.0-1.2$ & $10-50$ & $10-50$ & $3100-3900$ & $9.1-9.2$ \\
\hline Stn. 4 & Kis-Herlakni inner pond & $47^{\circ} 41.100^{\prime}$ & $16^{\circ} 42.173^{\prime}$ & $0.7-1.0$ & $10-50$ & $3-23$ & $2600-3800$ & $8.6-8.7$ \\
\hline Stn. 5 & Hidegségi inner pond & $47^{\circ} 40.530^{\prime}$ & $16^{\circ} 43.886^{\prime}$ & $0.8-1.0$ & $10-50$ & $6-27$ & $2300-3200$ & $8.4-8.8$ \\
\hline Stn. 6 & Bozi-canal & $47^{\circ} 38.947^{\prime}$ & $16^{\circ} 43.246^{\prime}$ & $0.3-1.1$ & $10-100$ & $2.7-10$ & $1000-1400$ & $7.8-8.4$ \\
\hline Stn. 7 & Bozi-canal & $47^{\circ} 38.743^{\prime}$ & $16^{\circ} 43.211^{\prime}$ & $0.3-1.0$ & $10-100$ & $1.2-38$ & $1000-1700$ & $7.8-8.4$ \\
\hline
\end{tabular}

* Based on a long term-data from 2003 to 2005.

Cell size measurements were performed on each species at least on 10 individuals. Cell numbers were converted to wet weight (biomass) by estimating cell volumes of individual species assuming a specific gravity of 1.0. For the picoalgal biomass estimation the cell diameter of picocyanobacteria was assumed to $1.1 \mu \mathrm{m}$, while the cell diameter of picoeukaryotic cells was assumed to $1.5 \mu \mathrm{m}$. These cell diameters were calculated from the diameter of 100 pico-sized cells using an Olympus BX51 differential interference contrast microscope.

\section{Molecular analysis}

After having concentrated a $50-100 \mathrm{~mL}$ water sample by centrifugation $(5000 \times g, 10 \mathrm{~min}), 0.6 \mathrm{~mL} \quad \mathrm{CLS}-\mathrm{Y}$ (Bio101 Systems, Q-Biogene), $300 \mathrm{mg}$ glass bead and approximately $5 \mathrm{mg}$ of polyvinyl-polypyrrolidone were added. The cells were disrupted in a Retsch MM301 extractor (1 min, $30 \mathrm{~s}$ ). Purification of the genomic DNA was carried out with the Bacterial Genomic DNA MiniPrep Kit (V-gene Biotechnology Ltd.). PCRs were performed as described by Felföldi et al. (2009). Primer sequences and the temperature cycling parameters are given in Nübel et al. (1997) for the specific amplification of partial 16S rDNA from cyanobacteria and plastids (using primers CYA106F and CYA781R) and in Robertson et al. (2001) to amplify the $c p c B A$-IGS region specifically for the genus Synechococcus (using primers cpcBF(UFP) and cpcAR(URP)). The purified PCR products (generated with the PCR-M ${ }^{\mathrm{TM}}$ Clean Up System, Viogene) were cloned using the TOPO TA Cloning ${ }^{\circledR}$ Kit containing pCR $^{\circledR}$ 2.1-TOPO ${ }^{\circledR}$ (Invitrogen ${ }^{\mathrm{TM}}$ ) vector. Sequence analysis was performed with clones having different restriction pattern (generated with the endonucleases AluI and $B s u \mathrm{RI})$ using the BigDye ${ }^{\circledR}$ Terminator v3.1 Cycle Sequencing Kit (Applied Biosystems). The chromatograms were corrected manually and primer sequences were removed using the Chromas software, version 1.45 (Technelysium Pty Ltd, Australia).

Sequences were compared to the GenBank nucleotide database using blastn 2.2.18 (Altschul et al., 1997). Neighbor-joining (Saitou and Nei, 1987) phylogenetic trees were constructed with the MEGA4 software (Tamura et al., 2007) using only unambiguous (gaps and missing data were eliminated) positions of a ClustalW alignment (Thompson et al., 1994), evolutionary distances were computed using the Kimura 2-parameter method (Kimura, 1980). Sequences obtained in this study have been submitted to GenBank under the following accession numbers EU914860-EU914885 (16S rDNA) and EU926148-EU926156 (cpcBA-IGS).

\section{Statistical analysis}

Picophytoplankton abundance, composition and Secchi-disk transparency of different water bodies (open water, inner ponds and artificial canal) was compared by non-parametric Kruskal-Wallis ANOVA using the OriginPro 8 sotftware. The difference was considered to be significant when $P<0.05$.

The phytoplankton composition in the different water bodies was compared based on all complete sampling data (April, June and October) by Detrended Correspondance Analysis (DCA) using PCOrd software. Tychoplanktonic species were excluded from the analysis and rare species were down-weighted.

\section{Results}

\section{Study site measurements}

The physical and chemical parameters of the different sampling sites were very similar, only Stn. 6 and Stn. 7 had lower $\mathrm{pH}$ and conductivity (Table 1). The conductivity varied between 2200 and $3900 \mu \mathrm{S} . \mathrm{cm}^{-1}$, the $\mathrm{pH}$ ranged between 8.4 and 9.3 in the open water and the inner ponds. In the artificial canal, the conductivity varied between $1000-1700 \mu \mathrm{S} . \mathrm{cm}^{-1}$ and the $\mathrm{pH}$ ranged between 7.8 and 8.4. The open water area had white- or grey-coloured turbid water, the inorganic suspended solid concentration ranged from 12 to $260 \mathrm{mg} . \mathrm{L}^{-1}$. The inner ponds had more transparent brownish water (suspended solids: 3-50 mg. $\mathrm{L}^{-1}$ ) similarly to the canal (suspended solids: 1-38 mg.L ${ }^{-1}$, Table 1). Between 2003 and 2005, the Secchi-disk transparency ranged from 2.5 to $30 \mathrm{~cm}$ in the open water area of the lake, 10 to $50 \mathrm{~cm}$ in the inner ponds and 10 to $100 \mathrm{~cm}$ in the artificial canal (Table 1). 
Table 2. Phytoplankton biomass (chlorophyll $a$ ) in Lake Fertő (Neusiedlersee) in 2004 (n. d. = no data).

\begin{tabular}{lcccccc}
\hline $\begin{array}{l}\text { Chlorophyll } a \\
\left(\mu \mathrm{g} . L^{-1}\right)\end{array}$ & Stn. 1 & Stn. 2 & Stn. 3 & Stn. 4 & Stn. 5 & Stn. 6 \\
\hline April & 31 & 26 & 15 & 10 & 10 & 7 \\
June & 21 & 12 & 18 & 7 & 10 & 8 \\
August & 11 & 17 & n. d. & 12 & 13 & n. d. \\
October & 3 & 7 & 6 & 11 & 8 & n. d. \\
\hline
\end{tabular}

\section{Algological investigations}

The biomass of the phytoplankton varied in a wide range during the study period (chlorophyll $a$ concentration: $3-59 \mu \mathrm{g} . \mathrm{L}^{-1}$, total phytoplankton biomass: $0.057-$ 14.9 mg. $\mathrm{L}^{-1}$ ) (Table 2). The maximum value was measured at Stn. 7 in April. The open water of the lake was mesotrophic (mean chlorophyll a concentration: $16 \mu \mathrm{g} . \mathrm{L}^{-1}$, mean total phytoplankton biomass: $2.2 \mathrm{mg} . \mathrm{L}^{-1}$ ) likewise the inner ponds (mean chlorophyll $a$ concentration: $11 \mu \mathrm{g} . \mathrm{L}^{-1}$, mean total phytoplankton biomass: $1.9 \mathrm{mg} . \mathrm{L}^{-1}$ ) and the Bozi-canal (mean chlorophyll $a$ concentration: $17 \mu \mathrm{g} . \mathrm{L}^{-1}$, mean total phytoplankton biomass: $3.6 \mathrm{mg} . \mathrm{L}^{-1}$ ). There was a significant positive correlation between total phytoplankton biomass and chlorophyll $a$ concentration $\left(\mathrm{r}^{2}=0.84, P<0.001\right)$. The chlorophyll $a$ content of the total phytoplankton biomass ranged between 0.23 and $1.7 \%$, the average value was $0.83 \%$.

The total picoplankton abundance varied between 0.04-51 $\times 10^{5}$ cells.mL ${ }^{-1}$ with an average of $7.8 \times 10^{5}$ cells. $\mathrm{mL}^{-1}$ considering all sampling stations during the investigation period (Fig. 1). Both single-celled picoeukaryotes and single-celled or colonial picocyanobacteria were present, but within the picocyanobacteria only phycocyanin-rich cells were observed. The highest abundance values were measured at all sampling stations in April. The abundance of picocyanobacteria was on the average two magnitudes higher than that of picoeukaryotes. The highest picocyanobacterium abundance values were measured in the open-water area (Stn. 1: $46.6 \times$ $10^{5}$ cells. $\mathrm{mL}^{-1}$ and Stn. 2: $51 \times 10^{5}$ cells. $\mathrm{mL}^{-1}$ ). At this time colonial forms of cyanobacteria constituted one half of the picoplankton. Picoeukaryotes were found $(0.2-$ $0.4 \times 10^{5}$ cells. $\mathrm{mL}^{-1}$ ) exclusively in the inner ponds (only in April and October). The picoplankton of the artificial canal (Stn. 6 and Stn. 7) was negligible $(0.04-0.1 \times$ $10^{5}$ cells. $\mathrm{mL}^{-1}$ ) during the study period (Fig. 1).

The autotrophic picoplankton played a very important role in the composition of the phytoplankton at the open water sampling stations and in the inner ponds (Fig. 2). The picoplankton contribution was high in April and October (up to 80\%). Among larger Cyanobacteria, Planktothrix agardhii (Gomont) Anagnostidis \& Komárek had significant role in Stn. 2 in October $(24 \%$, Fig. 2). Euglenophyta species were observable at the open water sampling stations and in the inner ponds (10-20\%, Fig. 2). The contribution of Cryptophyta species was high at Stn. $4(50 \%)$ and Stn. $5(35 \%)$ in June as well as at Stn. 6 in June $(73 \%)$ and October $(60 \%)$. The most frequent

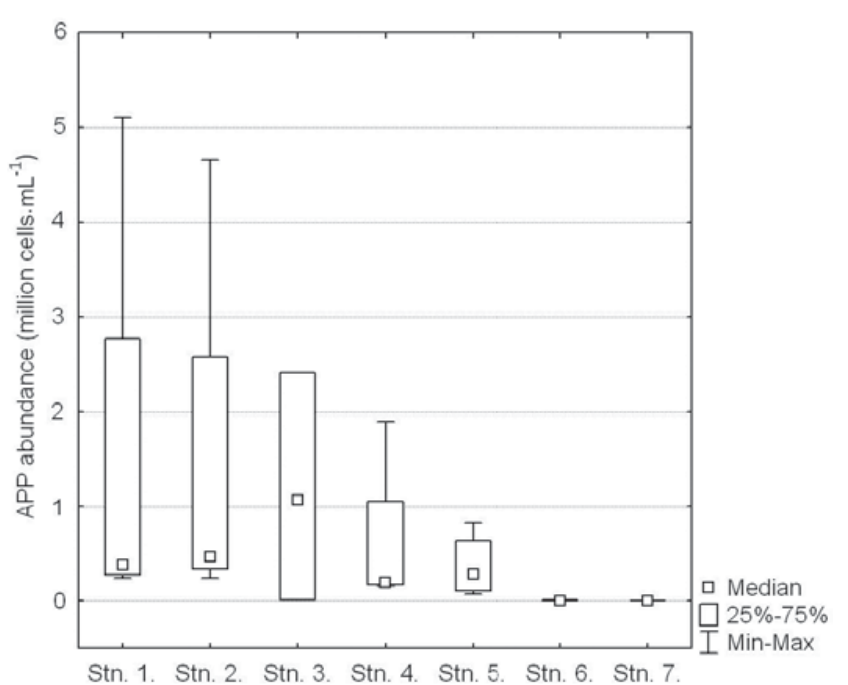

Fig. 1. Autotrophic picoplankton (APP) abundance (median values with minimum and maximum are given) at the different sampling stations in Lake Fertő in 2004.

species were Rhodomonas minuta $v$. nannoplanctonica Skuja, Cryptomonas ovata Ehrenberg and Cryptomonas reflexa Skuja. Dinophyta species were observed considerably only in August: Peridinium aculiferum Lemm. constituted $22-27 \%$ of the total phytoplankton biomass at Stn. 4 and Stn. 5 (Fig. 2). Diatoms (Heterokontophyta) were the most characteristic members (usually $>50 \%$ ) of the phytoplankton; however, mostly meroplanktonic species were detected (Fig. 2). In the open water and the inner ponds Campylodiscus clypeus Ehrenberg was the most common; however, in October Cyclotella species dominated the phytoplankton at Stn. 4 (Fig. 2). In the artificial canal mainly epiphytic diatoms (Diatoma tenuis Agardh. and Fragilaria ulna (Nitzsch) Lange-Bertalot) were dominant. The members of the Chlorophyta played significant role only in the artificial canal (Fig. 2). At Stn. 6 Carteria species constituted $50 \%$ of the phytoplankton in April, while at Stn. 7 Spirogyra species (benthic) were dominant $(97 \%)$ in October.

\section{Molecular analysis}

The majority of our $16 \mathrm{~S}$ rDNA clones clustered within the nonmarine members of the picophytoplankton clade sensu Urbach et al. (1998) (Fig. 3). In case of Stn. 1 clone library, 154 clones were investigated and according to the differences in their restriction patterns 16 representative clones were subjected to sequence analysis. Based on these 

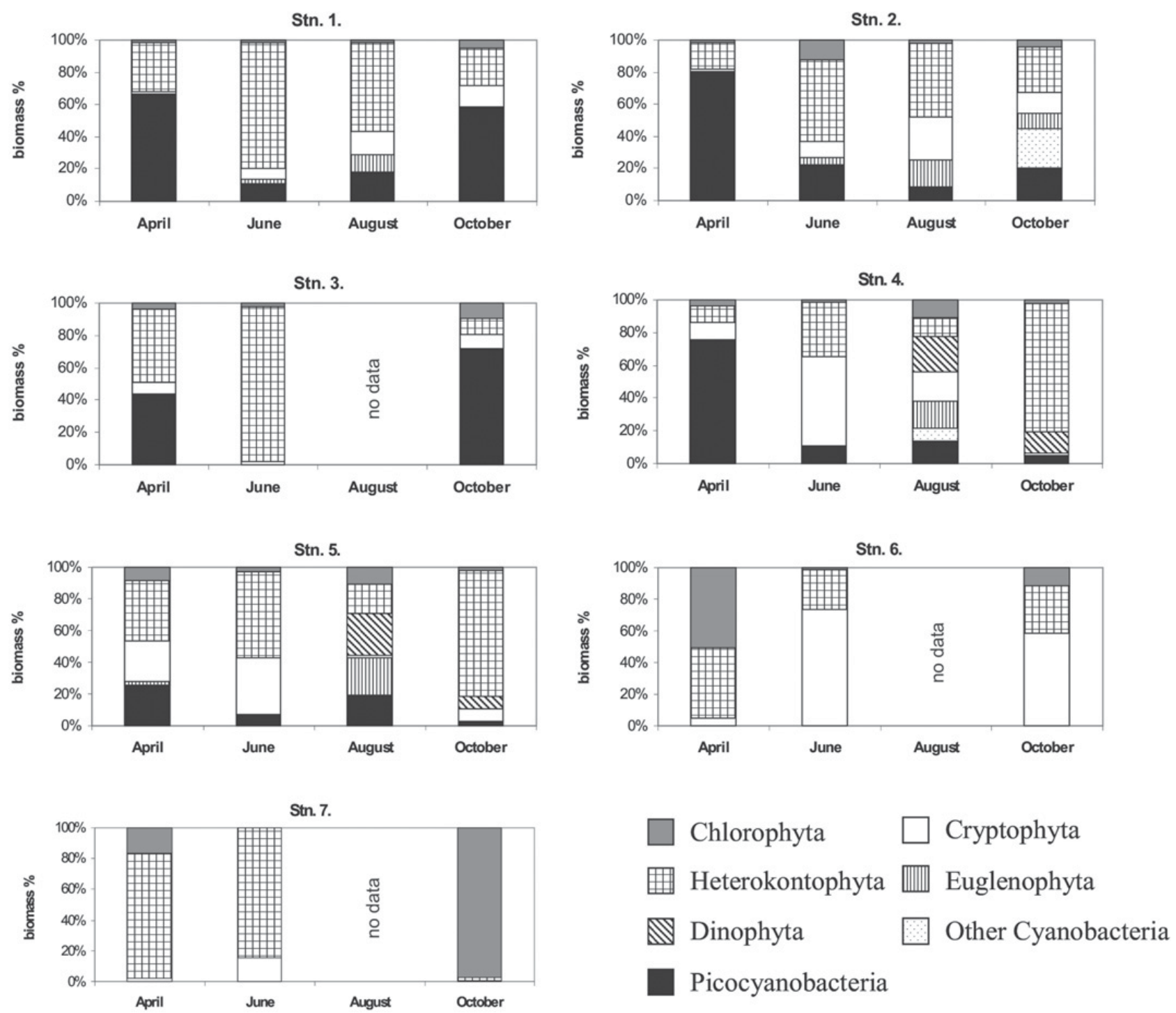

Fig. 2. Phytoplankton composition at the different sampling stations in Lake Fertő in 2004.

results, $96 \%$ of the clone library could be affiliated to picocyanobacteria; $65 \%$ to group A (Cyanobium gracile cluster), $33 \%$ to group B (subalpine cluster I) and 2\% (represented by clone St1r121 and St1r164) fell outside the previously defined groups. In case of Stn. 2 clone library, 167 clones were investigated and ten representative clones were subjected to sequence analysis. Similarly to Stn. 1, $96 \%$ of the clone library could be affiliated to picocyanobacteria; $72 \%$ to group A, $25 \%$ to group B and $3 \%$ (represented by clone St2r138) fell outside the previously defined groups.

We also detected sequences derived from larger Cyanobacteria and from plastids (distantly related to identified Chlorophyta and Bacillariophyta isolates, Fig. 3) and heterotrophic bacteria (Verrucomicrobia, data not shown).

In case of the $c p c B A$-IGS clone library (constructed from Stn. 1), 69 clones were investigated and nine representative clones were subjected to sequence analysis. Most of the clones (84\%) fell within group A, $13 \%$ of the clones could be affiliated to group $\mathrm{C}$ and $3 \%$ of the clone library (represented by clone St1c6) shared low similarity $(88 \%)$ with previously determined sequences (Fig. 4). In contrast with the 16S rDNA clone library, no group B clones were found, but an additional cluster (group C) was identified in the lake based on the $c p c B A$-IGS region (unfortunately there is no available $16 \mathrm{~S}$ rDNA sequence from group $\mathrm{C}$ to date).

\section{Statistical analysis}

Picophytoplankton abundance (Kruskal-Wallis test: $\mathrm{H}$ $(2, N=25)=14.3, P=0.0008)$ and contribution (KruskalWallis test: $\mathrm{H}(2, N=25)=13.7, P=0.0011)$ were significantly lower in the artificial canal than in the other water bodies. Significant differences were not found between the open water and the inner ponds (Fig. 5). Secchi-disk transparency was also significantly higher 


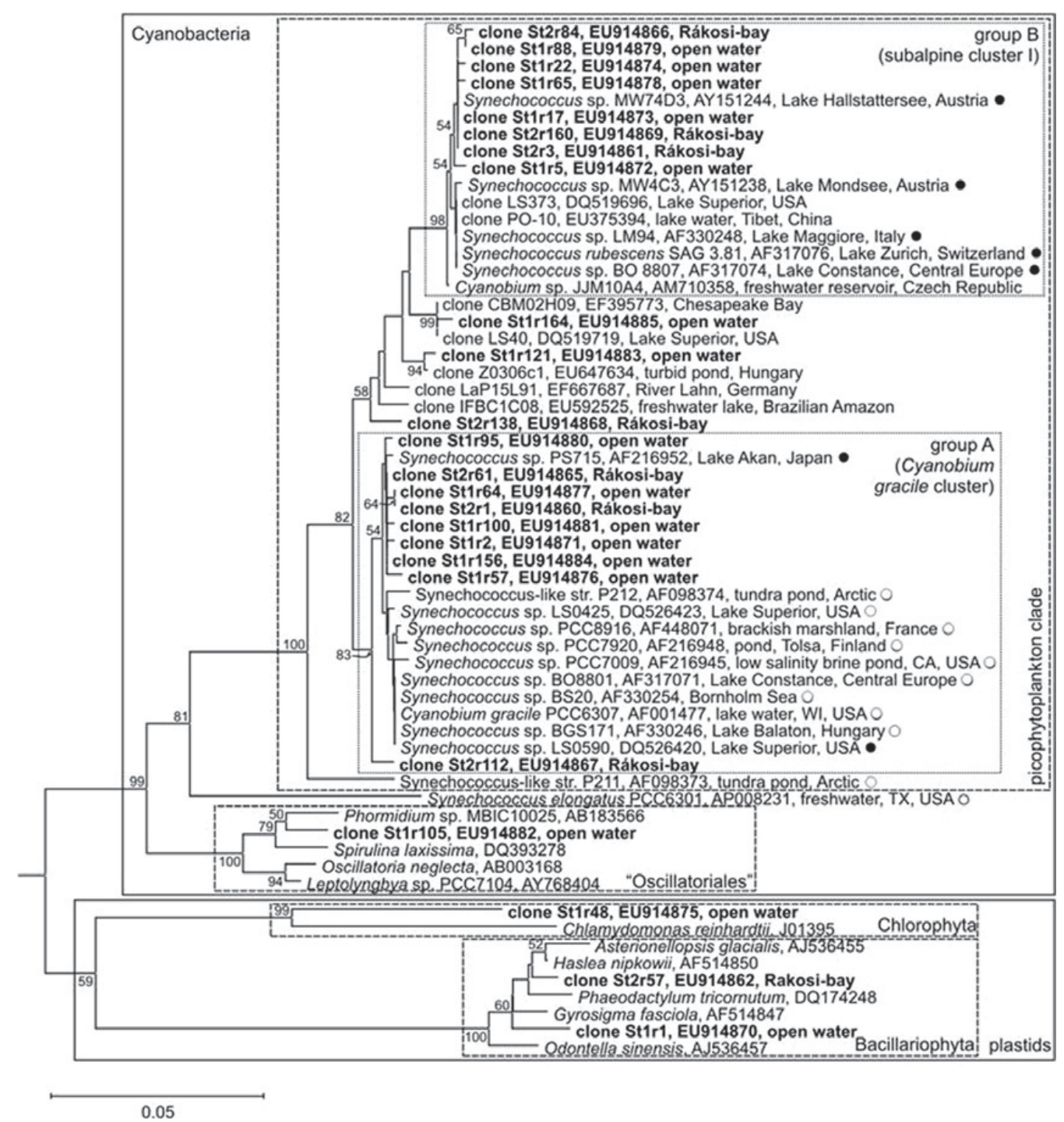

Fig. 3. Evolutionary relationships of environmental clones recovered from Lake Fertő based on 550 nucleotide positions of the $16 \mathrm{~S}$ ribosomal RNA gene. Bootstrap values higher than 50\% are shown. Pigment groups (•: phycoerythrin-rich, $\bigcirc$ : phycocyanin-rich) are shown for picocyanobacterial isolates. Sequences determined in this study appear in bold letters. Thermotoga maritima (M21774) was used as an outgroup (distance not shown). Cluster designations are according to Robertson et al. (2001), Crosbie et al. (2003) and Ernst et al. (2003).

only in the artificial canal (Kruskal-Wallis test: $\mathrm{H}(2$, $N=167)=64.5, P=0.00001$, Fig. 5).

Based on DCA analysis - in which the first axis explained $33.9 \%$, the second axis $22.4 \%$ of variance - the phytoplankton composition of Stn. 6 and Stn. 7 (artificial canal) formed a well-separated group (Fig. 6). The open water sampling stations (Stn. 1-Stn. 2) were clustered together, but were not separated clearly from the inner ponds (Stn. 3-Stn. 5, Fig. 6). Stn. 3 was similar to the open water cluster, while Stn. 4 and Stn. 5 were situated between the open water group and the artificial canal group (Fig. 6).

\section{Discussion}

Detailed information on the diversity of the picoplankton in Lake Fertő has been presented first time in this study. Based on both phylogenetic markers (16S rRNA gene and $c p c B A$-IGS region) the dominant group of picocyanobacteria belonged to the Cyanobium gracile cluster (group A) of the picophytoplankton clade ( $>65 \%$ of picocyanobacterial clones) in the open water in April. A previous work applying denaturing gradient gel electrophoresis (DGGE) analysis also supports these results (Felföldi et al., 2009). We confirmed the presence of two other picocyanobacterial groups representing minor populations of picocyanobacteria in Lake Fertő: group B and group C. According to former studies (e.g. Crosbie et al., 2003 and references therein) and the accumulating information in public nucleotide databases (GenBank, Benson et al., 2008), all three groups consist sequences derived from picocyanobacteria inhabiting various water bodies in different geographical locations. Group A contains a bulk of sequences originating from a wide 


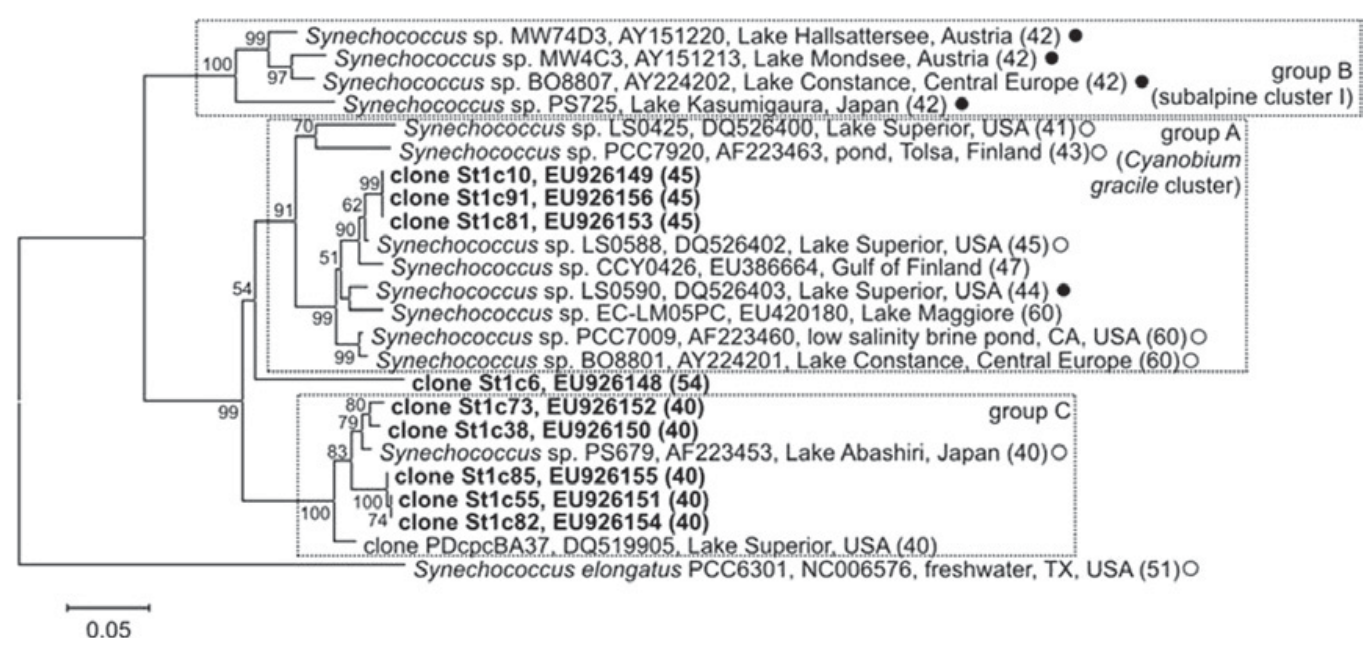

Fig. 4. Evolutionary relationships of environmental clones recovered from Lake Fertö based on 378 nucleotide positions of the $c p c B A$ IGS region (phycocyanin operon). For details see the caption of Figure 3. The length of the IGS region is shown in parentheses. Synechococcus elongatus PCC6301 was used as outgroup.

gradient of aquatic ecosystems from an ultraoligotrophic freshwater lake (Lake Superior) to a turbid, shallow lake (this study) and brackish or saline environments (e.g. Baltic Sea) (Figs. 3 and 4). Although group B and group C picocyanbacteria seemed to have limited distribution (Robertson et al., 2001; Ernst et al., 2003), increased picoplankton investigations revealed a more widespread occurrence of these groups (Crosbie et al., 2003; Ivanikova et al., 2007; Haverkamp et al., 2008; Sánchez-Baracaldo et al., 2008; this study). This widespread dispersal of some closely related picocyanobacterial phylotypes may confirm the high adaptive potential of these groups. It should be also noted that significant genetic diversity was found in all groups of picocyanobacteria detected in Lake Fertő.

Molecular analysis served evidence for the existence of other picocyanobacterial phylotypes in the lake outside the clusters/groups defined by previous studies (Robertson et al., 2001; Crosbie et al., 2003; Ernst et al., 2003; Ivanikova et al., 2007). These could be divided into three groups, since the pairwise similarity values between the 16S rDNA sequences outside the previously defined groups (clone St1r121, St1r164 and St2r138) were lower (97.6-98.3\%) than between the clones clustering to group A (98.5-100\%) or group B (99.1-100\%). Some of them (e.g. the $c p c B A$-IGS clone St1c6) may unique for Lake Fertő, as new picocyanobacterial clusters were also reported from Lake Superior (Ivanikova et al., 2007) or from freshwater lakes in England (Sánchez-Baracaldo et al., 2008), but increased sampling may reduce the number of unique picoalgal groups.

Interestingly, group B picocyanobacteria were detected only in the $16 \mathrm{~S}$ rDNA clone libraries and members of this group were not presented within the $c p c B A$-IGS clones. This could be the result of differences in the specificity of the two primer sets that may result in the preferential amplification of taxa (Sipos et al., 2007). We cannot rule out the possibility that the members of group $\mathrm{C}$ were presented among the $16 \mathrm{~S}$ rDNA clones (one of the ungrouped sequences), but they cannot be clearly assigned to this group since no $16 \mathrm{~S}$ rDNA sequences are available to date from group $\mathrm{C}$. We should emphazise that genetic composition of picocyanobacteria could also have an annual cycle in freshwater ecosystems with the periodic dominance of certain phylotypes (Becker et al., 2007; Ivanikova et al., 2007; Sánchez-Baracaldo et al., 2008). Therefore it is likely that the groups reported here as major types of picocyanobacteria have only seasonal dominance in Lake Ferto" in the open water. Picocyanobacterial composition of other water types (inner ponds and artificial canals) may also differ from the open water area, as community structure of picoalgae could have significant spatial variation (Ivanikova et al., 2007).

Based on the composition of the phytoplankton, remarkable differences were detected between the sampling stations. The artificial canal sampling stations composed a clearly separated group (Fig. 6), and the open water sampling stations also clustered together (Fig. 6). In the artificial canal epiphytic diatoms (D. tenuis and F. ulna), cryptophytes (Cryptomonas spp.) and chlorophytes (Carteria sp. and Spirogyra sp.) were the most abundant and the picoplankton was negligible, while the open water sampling stations were characterized by the dominance of picocyanobacteria and meroplanktonic diatoms (mainly C. clypeus) (Fig. 2). The inner ponds were positioned between these two groups (the characteristic species of the open water and the calm water of the reed belt also occurred), however, the largest one (Stn. 3) was close to the open water (Fig. 6). The abundance $\left(>10^{6}\right.$ cells. $\mathrm{mL}^{-1}$ ) and contribution (up to $80 \%$ ) of the picoplankton to the total phytoplankton biomass was very high in the open water and also in the inner ponds as compared to shallow, mesotrophic lakes (Vörös, 1989; Jasser, 1997; Szelag-Wasielewska, 1997, 2003). Similarly high picophytoplankton abundances were described (more than $10^{6}$ cells.mL ${ }^{-1}$ ) in freshwater and brackish systems (lagoons and saltmarshes) spanning a wide range of 

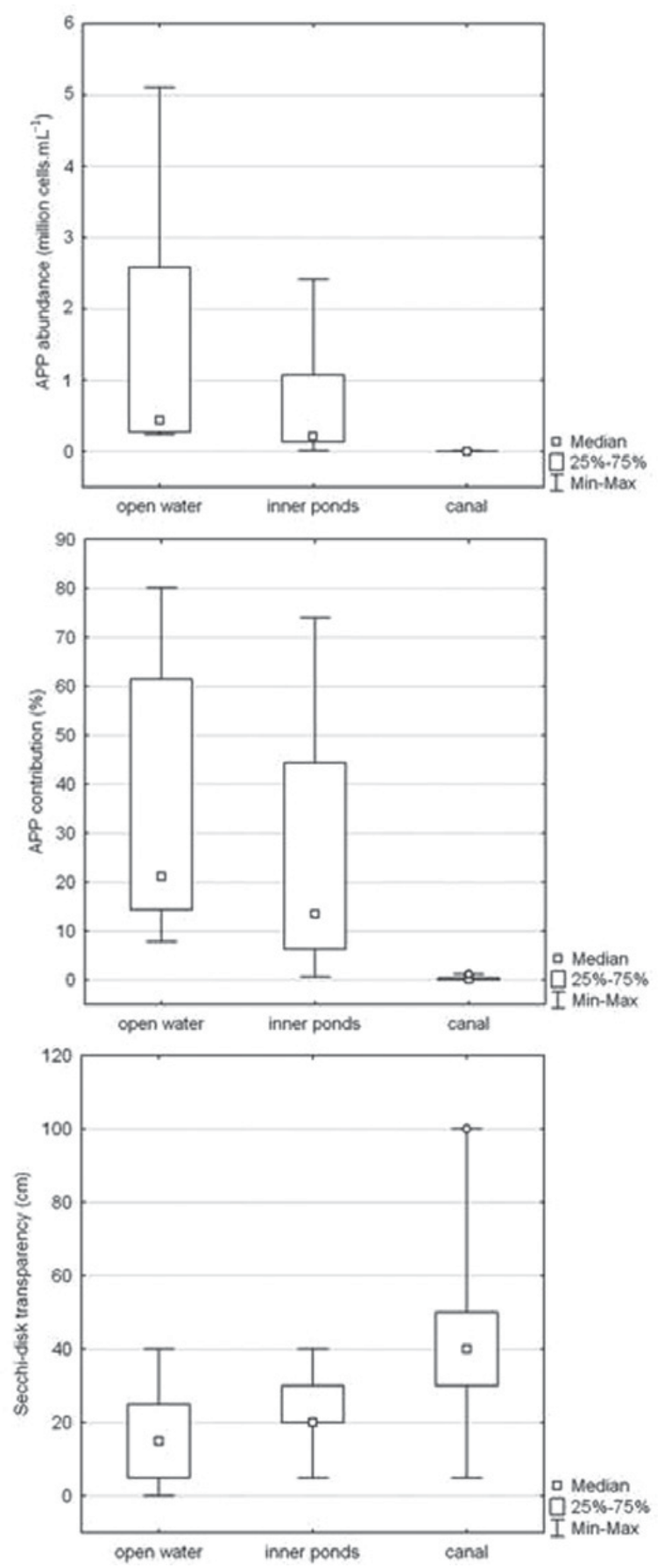

Fig. 5. Autotrophic picoplankton abundance, contribution and Secchi-disk transparency (median values with minimum and maximum are given) at different water bodies of Lake Fertö in 2004 .

trophic states (Stockner, 1991; Vörös et al., 1991; Carrick and Schleske, 1997; Hepperle and Krienitz, 2001; Del Negro et al., 2007; Felföldi et al., 2009; Somogyi et al., 2009). Although it is very hard to find a perfect model for picophytoplankton success in aquatic systems (Callieri, 2008), a widely accepted trend is the increase of the picophytoplankton abundance and the decrease of their contribution (to the total phytoplankton) with the increasing trophic state (Szelag-Wasielewska, 1997; Vörös et al., 1998; Bell and Kalff, 2001; Callieri, 2008). According to this, oligotrophic shallow lakes has been supposed to have moderate $\left(\sim 10^{3}-10^{5}\right.$ cells. $\left.\mathrm{mL}^{-1}\right)$ picophytoplankton abundance with high contribution, while eutrophic systems has been supposed to have higher abundance $\left(\sim 10^{5}\right.$ $10^{6}$ cells. $\mathrm{mL}^{-1}$ ) but lower contribution (Vörös et al., 1998; Callieri, 2008).

We hypothesize that the high magnitude of the picophytoplankton in the mesotrophic Lake Ferto" is in connection with the turbid environment. In this study, the abundance and contribution of the picoplankton were significantly higher in the open water and the inner ponds, where the Secchi-disk transparency was significantly lower than in the artificial canal. Several authors have described the decline of the zooplankton (including rotifers and daphnids) feeding with increasing turbulence and turbidity (G.-Tóth et al., 1986; Hart, 1988; Miquelis et al., 1998; Levine et al., 2005). In Lake Fertő, Herzig and Koste (1989) demonstrated the negative influence of the suspended solid particles on the development of Hexarthra (Rotifera) populations. Nevertheless, ciliates and heterotrophic nanoflagellates are supposed to be the main grazers of picoplankton in aquatic environments. The increased turbulence or turbidity led to lower growth rates of ciliates (Strobilidium sp.) in the study of Jack and Gilbert (1993) and Dolan et al. (2003). In Lake Fertö, Schönberger (1994) found higher bacteriovore ciliate abundance values (Halteria grandinella (Müller) Dujardin) in a transparent inner pond than in the turbid open water. Pfandl and Boenigk (2006) studied the effect of suspended particles on colourless chrysomonad flagellates, which are often the most important grazers of bacteria-sized microorganisms. It has been found, that small suspended particles in the size range of ingestible bacteria interfere with the feeding process of flagellates and cause lower clearance rates (Pfandl and Boenigk, 2006). Although, we should keep in mind that the increased surface to volume ratio of the small picoalgal cells is hypothesized to be affiliated with better light utilization (Agustí, 1991; Raven, 1998) and could account for the selective advantage of the pico-sized fraction in turbid, light-limited environments.

Our study revealed that the picoplankton in the mesotrophic Lake Fertő does not follow the general trend concerning the relation between the picoplankton abundance or contribution and the trophic state (SzelagWasielewska, 1997; Vörös et al., 1998; Bell and Kalff, 2001; Callieri, 2008). The low contribution of picoplankton in eutrophic systems also seems to be outworn as some studies - all focusing to turbid, low transparent waters found extremely high picoplankton abundance $\left(10^{6}-10^{8}\right)$ and contribution (90-100\%) in hypertrophic ponds or shallow lakes (Carrick and Schleske, 1997; Hepperle and Krienitz, 2001; Vörös et al., 2008; Somogyi et al., 2009). Up to now, the reason of these deviations is unknown, but the high turbidity seems to be the common feature of these systems. We suggest that success of picophytoplankton in turbid environments is the result of the combination of 


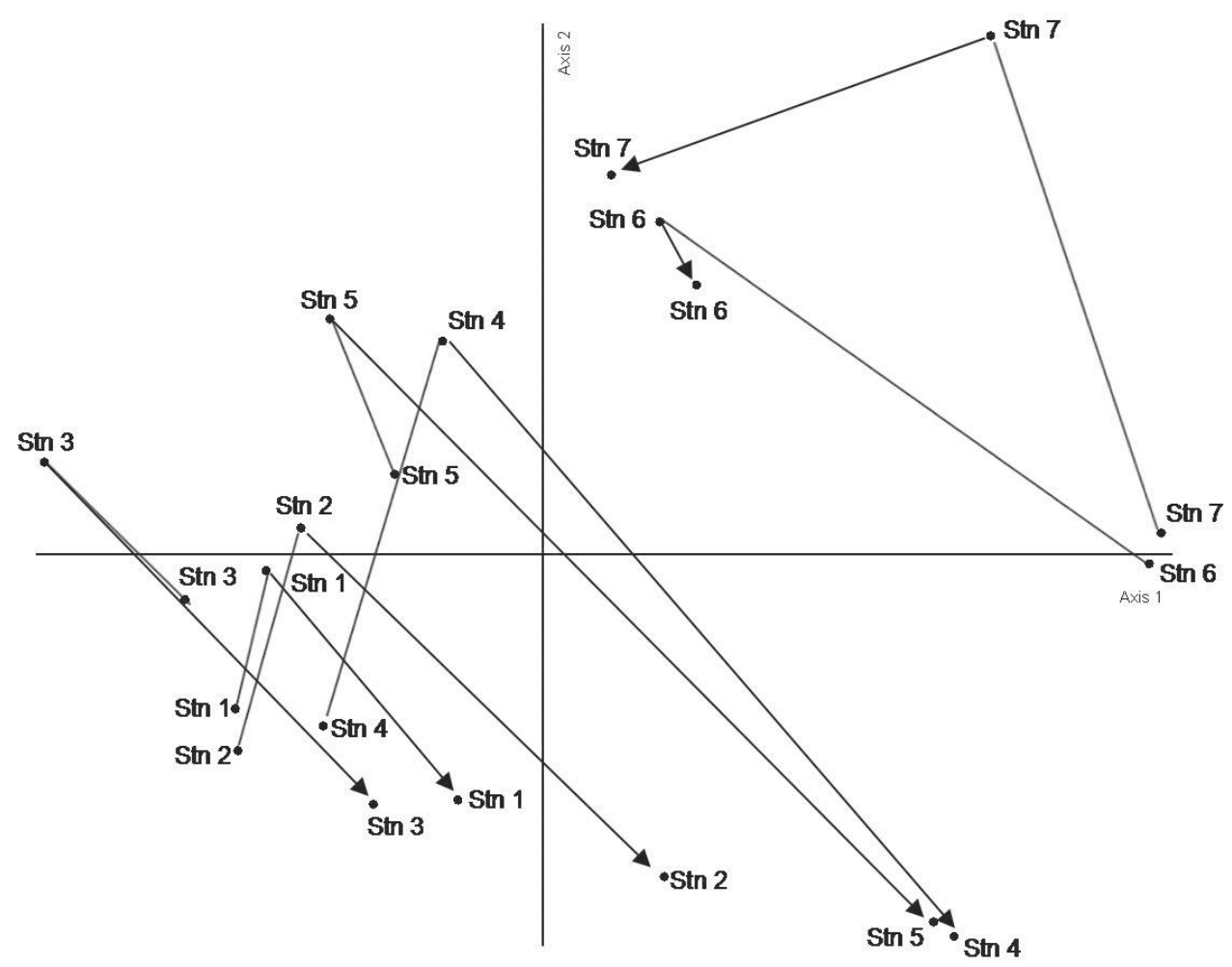

Fig. 6. Detrended correspondence analysis (DCA) of the phytoplankton composition in the different water bodies of Lake Fertő in 2004. Stations are connected according to sampling dates (April, June and October 2004).

light-limitation and suppressed grazing control, but the verification of this hypothesis requires further empirical data, laboratory and field experiments.

Acknowledgements. The study was sponsored by the Hungarian Scientific Research Fund (OTKA K 73369). The authors thank to the staff of the North-Transdanubian Water Authority for their help during field-works and for providing the Secchi-disk transparency data and to Balázs Németh and Nicole Krohn for the technical assistance. The authors also thank to Emil Boros and Ágnes Vári for their help concerning the statistical analysis.

\section{References}

Agustí S., 1991. Allometric scaling of light absorption and scattering by phytoplankton cells. Can. J. Fish. Aquat. Sci., 48, 763-767.

Altschul S.F., Madden T.L., Schäffer A.A., Zhang J., Zhang Z., Miller W. and Lipman D.J., 1997. Gapped BLAST and PSIBLAST: a new generation of protein database search programs. Nucleic Acids Res., 25, 3389-3402.

Becker S., Richl P. and Ernst A., 2007. Seasonal and habitatrelated distribution pattern of Synechocccus genotypes in Lake Constance. FEMS Microbiol. Ecol., 62, 64-77.

Bell T. and Kalff J., 2001. The contribution of picoplankton in marine and freshwater system of different trophic status and depth. Limnol. Oceanogr., 46, 1243-1248.

Benson D.A., Karsch-Mizrachi I., Lipman D.J., Ostell J. and Wheeler D.L., 2008. GenBank. Nucleic Acids Res., 36, D25-D30.
Borsodi A.K., Farkas I. and Kurdi P., 1998. Numerical analysis of planktonic and reed biofilm bacterial communities of Lake Fertő (Neusiedlersee, Hungary/Austria). Wat. Res., 32, $1831-1840$

Buczkó K., 1989. About the spatial distribution of the algae and the quantitative development of periphyton in the Hungarian part of Lake Fertö (Neusiedler See). BFB-Bericht, 71, 11-124.

Callieri C., 2008. Picophytoplankton in freshwater ecosystems: the importance of small-sized phototrophs. Freshwat. Rev., 1, $1-28$.

Carrick H.J. and Schelske C.L., 1997. Have we overlooked the importance of small phytoplankton in productive waters? Limnol. Oceanogr., 42, 1613-1621.

Crosbie N.D., Pöckl M. and Weisse T., 2003. Dispersal and phylogenetic diversity of nonmarine picocyanobacteria, inferred from $16 \mathrm{~S}$ rRNA gene and $c p c B A$-intergenic spacer sequence analyses. Appl. Environ. Microbiol., 69, 5716-5721.

Del Negro P., Paoli A., Celussi M., Crevatin E., Valeri A., Larato C. and Fonda Umani S., 2007. Picoplanktonic cyanobacteria in different Adriatic brackish environments. Transit. Waters Bull., 3, 13-16.

Dinka M., Ágoston-Szabó E., Berczik Á. and Kutrucz Gy., 2004. Influence of water level fluctuation on the spatial dynamic of the water chemistry at Lake Fertö/Neusiedler See. Limnologica, 34, 48-56.

Dokulil M., 1979. Optical properties, colour and turbidity. In: Löffler H. (ed.), Neusiedlersee - Limnology of a shallow lake in Central Europe, Dr. W. Junk Publishers, The HagueBoston-London, 151-162.

Dolan J.R., Sall N., Metcalfe A. and Gasser B., 2003. Effects of turbulence on the feeding and growth of a marine oligotrich ciliate. Aquat. Microb. Ecol., 31, 183-192. 
Eaton A.D., Clesceri L.S. and Greenberg A.E., 1995. Solids. In: Standard Methods, 19th edn., American Public Health Association, 2-56-2-57.

Ernst A., Becker S., Wollenzien U.I. and Postius C., 2003. Ecosystem-dependent adaptive radiations of picocyanobacteria interred from 16S rRNA and ITS-1 sequence analysis. Microbiology (UK), 149, 217-228.

Felföldi T., Somogyi B., Marialigeti K. and Vörös L., 2009. Characterization of photoautotrophic picoplankton assemblages in turbid, alkaline lakes of the Carpathian Basin (Central Europe). J. Limnol., 68, 385-395.

G.-Tóth L., V.-Balogh K. and Zánkai N., 1986. Significance and degree of abioseston consumption in the filter-feeder Daphnia galeata Sars. Am. Richard (Cladocera) in Lake Balaton. Arch. Hydrobiol., 106, 45-60.

Hart R.C., 1988. Zooplankton feeding rates in relation to suspended sediment content: potential influences on community structure in a turbid reservoir. Freshwat. Biol., 19, 123-139.

Haverkamp T., Acinas S.G., Doeleman M., Stomp M., Huisman J. and Stal L.J., 2008. Diversity and phylogeny of Baltic Sea picocyanobacteria inferred from their ITS and phycobiliprotein operons. Environ. Microbiol., 10, 174-188.

Hepperle D. and Krienitz L., 2001. Systematics and ecology of chlorophyte picoplankton in German inland waters along a nutrient gradient. Int. Rev. Hydrobiol., 86, 269-284.

Herzig A. and Koste W., 1989. The development of Hexathra spp. in a shallow alkaline lake. Hydrobiologia, 186/187, 129-136.

Ivanikova N.V., Popels L.C., McKay M.L. and Bullerjahn G.S., 2007. Lake Superior supports novel clusters of cyanobacterial picoplankton. Appl. Environ. Microbiol., 73, 4055-4065.

Jack J.D. and Gilbert J.J., 1993. The effect of suspended clay on ciliate population growth rates. Freshwat. Biol., 29, 385-394.

Jasser I., 1997. The dynamics and importance of picoplankton in shallow, dystrophic lake in comparison with surface waters of two deep lakes with contrasting trophic status. Hydrobiologia, 342/343, 87-93.

Kimura M., 1980. A simple method for estimating evolutionary rate of base substitutions through comparative studies of nucleotide sequences. J. Mol. Evol., 16, 111-120.

Levine S.N., Zehrer R.F. and Burns C.W., 2005. Impact of resuspended sediment on zooplankton feeding in Lake Waihola, New Zealand. Freshwater Biol., 50, 1515-1536.

MacIsaac E.A. and Stockner J.G., 1993. Enumeration of phototrophic picoplankton by autofluorescence microscopy. In: Kemp P.F., Sherr B.F., Sherr E.B. and Cole J.J. (eds.), Handbook of methods in aquatic microbial ecology, Lewis Publishers, Boca Raton, Ann Arbor, London, Tokyo, 187-197.

Miquelis A., Rougier C. and Pourriot R., 1998. Impact of turbulence and turbidity on the grazing rate of the rotifer Brachionus calyciflorus (Pallas). Hydrobiologia, 386, 203-211.

Mózes A., Présing M. and Vörös L., 2006. Seasonal dynamics of picocyanobacteria and picoeukaryotes in a large shallow lake (Lake Balaton, Hungary). Int. Rev. Hydrobiol., 91, 38-50.

Nübel U., Garcia-Pichel F. and Muyzer G., 1997. PCR primers to amplify $16 \mathrm{~S}$ rRNA genes from Cyanobacteria. Appl. Environ. Microbiol., 63, 3327-3332.

Padisák J., 1992. Species composition, spatial distribution and the seasonal and interannual dynamics of phytoplankton in brown-water lakes enclosed with reed belts (Neusiedlersee/ Fertö; Austria/Hungary). BFB-Bericht, 79, 13-29.

Padisák J. and Dokulil M., 1994. Meroplankton dynamics in a saline, turbulent, turbid shallow lake (Neusiedlersee, Austria and Hungary). Hydrobiologia, 289, 23-42.

Pfand K. and Boenigk J., 2006. Stuck in the mud: suspended sediments as a key issue for survival of chrysomonad flagellates. Aquat. Microb. Ecol., 45, 89-99.

Raven J.A., 1998. The twelfth Transley lecture. Small is beautiful: the picophytoplankton. Funct. Ecol., 12, 503-513.

Robertson B.R., Tezuka N. and Watanabe M.M., 2001. Phylogenetic analyses of Synechococcus strains (cyanobacteria) using sequences of $16 \mathrm{~S}$ rDNA and part of the phycocyanin operon reveal multiple evolutionary lines and reflect phycobilin content. Int. J. Syst. Evol. Microbiol., 51, 861-871.

Saitou N. and Nei M., 1987. The neighbor-joining method: A new method for reconstructing phylogenetic trees. Mol. Biol. Evol., 4, 406-425.

Sánchez-Baracaldo P., Handley B.A. and Hayes P.K., 2008. Picocyanobacterial community structure of freshwater lakes and the Baltic Sea revealed by phylogenetic analyses and clade-specific quantitative PCR. Microbiology (UK), 154, 3347-3357.

Schönberger M., 1994. Planktonic ciliated protozoa of Neusiedler See (Austria/Hungary) - a comparison between the turbid open lake and a reedless brown-water pond. Marine Microbial Food Webs, 8, 251-263.

Sipos R., Székely A.J., Palatinszky M., Révész S., Márialigeti K. and Nikolausz M., 2007. Effect of primer mismatch, annealing temperature and PCR cycle number on $16 \mathrm{~S}$ rRNA gene-targeting bacterial community analysis. FEMS Microbiol. Ecol., 60, 341-350.

Somogyi B., Felföldi T., Vanyovszki J., Ágyi Á., Márialigeti K. and Vörös L., 2009. Winter bloom of picoeukaryotes in Hungarian shallow turbid soda pans and the role of light and temperature. Aquat. Ecol., 43, 735-744.

Stockner J.G., 1991. Autotrophic picoplankton in freshwater ecosystems: The view from summit. Int. Rev. Ges. Hydrobiol., 76, 483-492.

Stockner J.G., Callieri C. and Cronberg G., 2000. Picoplankton and other non-bloom forming cyanobacteria in lakes. In: Whitton B.A. and Potts M. (eds.), The ecology of cyanobacteria-Their diversity in time and space, Kluwer Academic Publishers, Dordrecht, London, Boston, 195-231.

Szelag-Wasielewska E., 1997. Picoplankton and other size groups of phytoplankton in various shallow lakes. Hydrobiologia, 342/343, 79-85.

Szelag-Wasielewska E., 2003. Phytoplankton community structure in non-stratified lakes of Pomerania (NW Poland). Hydrobiologia, 506/509, 229-236.

Tamura K., Dudley J., Nei M. and Kumar S., 2007. MEGA4: Molecular Evolutionary Genetics Analysis (MEGA) software version 4.0. Mol. Biol. Evol., 24, 1596-1599.

Tevanné B.E., 1981. The algal flora of Lake Fertő. Hidrológiai Közlöny, 61, 97-144 [in Hungarian with German summary].

Thompson J.D., Higgins D.G. and Gibson T.J., 1994. Clustal W: improving the sensitivity of progressive multiple sequence alignment through sequence weighting, position-specific gap penalties and weight matrix choice. Nucleic Acids Res., 22, 4673-4680. 
Urbach E., Scanlan D.J., Distel D.L., Waterbury J.B. and Chisholm S.W., 1998. Rapid diversification of marine picophytoplankton with dissimilar light-harvesting structures inferred from sequences of Prochlorococcus and Synechococcus (Cyanobacteria). J. Mol. Evol., 46, 188-201.

Utermöhl H., 1958. Zur Vervolkommung der quantitativen Phytoplankton-Methodik. Mitt. Int. Ver. Limnol., 9, 1-38.

Vörös L., 1989. On the importance of the picoplankton in Lake Balaton (in Hungarian with English summary). Hidrológiai Közlöny, 69, 321-327.
Vörös L., Gulyás P. and Németh J., 1991. Occurrence, dynamics and production of picoplankton in Hungarian shallow lakes. Int. Rev. Ges. Hydrobiol., 76, 617-629.

Vörös L., Callieri C., V.-Balogh K. and Bertoni R., 1998. Freshwater picocyanobacteria along a trophic gradient and light quality range. Hydrobiologia, 369/370, 117-125.

Vörös L., Somogyi B. and Boros E., 2008. Birds cause net heterotrophy in shallow lakes. Acta Zool. Hung., 54, 23-34.

Wetzel R.G. and Likens G.E., 1991. Limnological Analyses, 2nd edn., Springer-Verlag, New York, 391 p. 